\title{
THE ALTERATION OF PRO- AND ANTI-INFLAMMATORY CYTOKINES IN ADRENALINE-CALCIUM INDUCED MYOCARDIAL DAMAGE AND ITS CORRECTION WITH QUERCETIN IN RATS
}

\author{
O. V. Denefil, A. M. Musiienko \\ I. HORBACHEVSKY TERNOPIL STATE MEDICAL UNIVERSITY, TERNOPIL, UKRAINE
}

Background. Cardiac insufficiency is one of the main causes of morbidity and mortality in the world.

Objective. The aim of the study was to determine the content of interleukins in male rats with adrenalinecalcium model of myocardial injury (ACM) and under correction by quercetin.

Methods. 143 Wistar male-rats aged 5-6 months were used in the experiments. The changes of interleukins (IL-1beta, IL-2, IL-4, IL-6, IL-10, TNF-alpha) content in blood serum in the development of heart injury by adrenaline and calcium (AC) and use of quercetin for protection were studied. The period of investigation was in 1, 2, 24 hours, 3, 7, 14, 21, 28 days.

Results. In ACM model of myocardial injury TNF-alpha increased, IL-2, IL-4 decreased at each period of investigation. IL-1beta increased in 2 and 3 days after the injury, at all other periods (except in 1 hour and 21 days) those indices were decreased. Also we observed similar wave changes of IL-6 and IL-10 content.

Injections of quercetin for 7 days caused a significant decrease of IL-2, IL-4, IL-10, and increase of IL-6. In 7 days of quercetin administration after AC-injury, decreased TNF-alpha was observed as well as increased IL-4, IL-6, and IL-1beta rates. In 14 days, the increase of TNF-alpha, normalization of IL-10 to control was evidenced. In 28 days, increased activation of IL-1beta, decreased content of TNF-alpha was fixed.

Conclusions. The development of adrenaline-calcium heart damage is accompanied by bright cytokine wavelike reaction at different time points. Quercetin causes normalization of interleukins level.

KEY WORDS: heart damage; rats; adrenaline-calcium model; quercetin; interleukins.

\section{Introduction}

Cardiac insufficiency is one of the main causes of morbidity and mortality in the world. One of the causes of its development is myocardial infarction, when cardiomyocytes die due to prolonged ischemia. Myocardial infarction is a dynamic process, which is accompanied by transition of reversible changes to irreversible ischemic damage and completes in replacement of the diminished part of myocardium by a fibrous scar. Development of fibrosis is a dysfunctional process in which myofibroblasts, the main fibrous cellular elements, are metabolically active and are able to produce and upregulate cytokines; they also have contractile properties [1]. Myocardial infarction leads to rapid necrosis of cardiac myocytes. To achieve tissue integrity and function, inflammatory cells are activated, including monocytes/macrophages. Impaired monocyte/ macrophage function is a not established new

Corresponding author: Olha Denefil, professor of Department of Pathophysiology, I. Horbachevsky Ternopil State Medical University, 1 Maydan Voli, Ternopil, 46001, Ukraine

E-mail: denefil@tdmu.edu.ua

Phone number: +380978536918 pathophysiological mechanism for left ventricular thrombus development after myocardial infarction [2]. Myocardial damage in myocardial infarction takes place mainly due to ischemic necrosis and inflammatory mechanisms while apoptosis is the main mechanism of cell death in 'reperfusion injury' in addition to limited ischemic necrosis [3].

In the diseased heart, cardiomyocytes are lost to necrotic cell death, and phenotypically transformed fibroblast-like cells, termed 'myofibroblasts', are activated to initiate a 'reparative' fibrosis. The structural integrity of myocardium is preserved by this scar tissue, although the expense of its remodeled structure, which increases tissue stiffness and propensity to arrhythmias. A persisting population of activated myofibroblasts turns this fibrous tissue into a living 'secretome' that generates angio_ tensin II and its type 1 receptor, fibrogenic growth factors, all of which collectively act as a signal-transducer-effector signaling pathway to type I collagen synthesis and, therefore, fibrosis. Persistent myofibroblasts, and the resultant fibrous tissue they produce, cause progressive adverse myocardial remodeling, a 
pathological hallmark of the failing heart irrespective of its etiologic origin [4].

Cardiomyocyte necrosis activates an inflammatory response that serves to clear the injured myocardium from dead cells, and stimulates repair, but may also extend injury. Recently the studies in the literature have identified interleukin-1a and RNA released by necrotic cardiomyocytes as key danger signals that trigger the inflammatory response following infarction. Interleukin-1 promotes activation of a proinflammatory phenotype in leukocytes and fibroblasts, and delays myofibroblast transdifferentiation. Inhibitory lymphocytes are crucial in negative regulation of postinfarction inflammatory response by modulating macrophage and fibroblast phenotype. Cardiac macrophages exhibit significant heterogeneity and phenotypic plasticity and may manage the reparative response following infarction. In adult mice- animals replacement of resident macrophage populations with monocyte-derived macrophages may induce inflammation while inhibiting cardiac regeneration [5].

Taking into account that the main pathogenic links are the development of inflammation, oxidative and nitric explosion, spasm of coronary vessels, necrosis, fibrosis, the study of the effectiveness of cardioprotective activities for the treatment of the basic pathogenesis is necessary. These medications include quercetin, which has antioxidant, anti-spasm, anti-inflammatory, antisclerotic properties [6].

Therefore, the aim of our study was to determine the content of interleukins in male rats with adrenalin-calcium model of myocardial injury (ACM) and to correct the pathological process by quercetin.

\section{Methods}

The experiments were performed on 143 albino Wistar male rats 5-6 months of age. The animals were divided into 14 groups (Table 1 ). Each group comprised 10 animals. The rats were once intramuscularly administered with a $0.18 \%$ solution of adrenaline hydrotartrate at a dose of $0.5 \mathrm{mg} / \mathrm{kg}$ of body weight (Pharmaceutical firm "Darnitsa", Ukraine) and intraperitoneally with $5 \%$ solution of calcium gluconate ("Dniprofarm", Ukraine) at a dose of $1 \mathrm{ml} / 100 \mathrm{~g}$ of body weight. For the correction the solution of quercetin at a dose of $200 \mathrm{mg} / \mathrm{kg}$ of body weight was injected intraperitoneally once a day for 7 days after adrenaline and calcium injections.

Experiments were performed in a special room in the morning at $18-22{ }^{\circ} \mathrm{C}$, relative humidity $40-60 \%$ and illumination 250 lux. The regulations of the European Convention for the Protection of Vertebrate Animals Used for Experimental and Other Scientific Purposes (Strasbourg, 1986), Resolution of the First National Congress on Bioethics (Kyiv, 2001) and the Order of the Ministry of Health of Ukraine № 690 dated September 23, 2009, were strictly followed.

The rats were euthanized by total heart bloodletting and previous thiopental sodium anesthesia $\left(60 \mathrm{mg} \cdot \mathrm{kg}^{-1}\right.$ of body weight intraperitoneally). Blood samples were taken for the research. Concentration of interleukins IL-1 beta, IL-2, IL-4, IL-6, IL-10, tumor necrosis factor alpha (TNF-alpha) was determined in blood serum by the method of immunoenzyme analysis using a set of reagents produced by ZAO vector-Best (Russia).

Table 1. Division of animals by groups 
A statistical analysis of digital data was performed by means of Excel (Microsoft, USA) and STATISTICA 6.0 (Statsoft, USA). Statistical significance of the differences between independent indices was estimated by Student t-test at normal distribution and by nonparametric methods in other cases.

\section{Results}

In 1 hour after adrenaline and calcium injection, the increase of TNF-alpha in 7.56 times $(p<0.001)$, decrease of IL- 4 by $35.63 \%$ $(p<0.001)$ and of $\mathrm{H}-10$ by $46.08 \%(p<0.001)$ were determined (Table 2 ).

In 2 hours IL-1 beta was increased by $45.69 \%(p<0.001)$ and TNF-alpha - in 5.9 times $(p<0.001)$; IL-2 was decreased by $18.24 \%$ $(p<0.002)$ and IL- 6 - by $48.57 \%(p<0.001)$. The increase of IL-1 beta by $45.82 \%(p<0.01)$, of IL-10 in 2.1 times $(p<0.001)$, the decrease of IL- 6 by $47.55 \%(p<0.001)$ were determined compared with the previous study.

In 1 day, compared to the control, there was a decrease of IL-1beta by $38.58 \%(p<0.001)$, IL-2 - by $30.40 \%(p<0.001)$, IL- 4 - by $23.45 \%$ $(p<0.001)$, and increase of IL-6 in $46.68 \%$ $(p<0.01)$, TNF-alpha - in 5.21 times $(p<0.001)$, and compared to the previous study, there was a decrease of IL-1 beta by $57.84 \%(p<0.001)$, IL-2 - by $14.88 \%(p<0.01)$, IL-10 - by $23.37 \%$ $(p<0.01)$, increase of IL- 6 in 2.85 times $(p<0.001)$.

In 3 days, compared to the control, the level of IL-1 beta was higher by $21.94 \%(p<0.001)$, TNF-alpha - in 7.06 times $(p<0.01)$, IL-10 - by $37.16 \%(p<0.001)$, and IL-2 was lower by $56.08 \%$ $(p<0.001)$, IL-4 - by $39.66 \%(p<0.001)$, IL- 6 - by $34.67 \%(p<0.01)$, and compared with the previous period, IL-1beta was increased by $22.06 \%(p<0.001)$, IL-10 - in 2.547 times $(p<0.001)$, IL-2 was decreased by $83.20 \%$ $(p<0.02)$, IL- 6 - by $33.38 \%(p<0.001)$, IL-4 - by $6.26 \%(p<0.001)$.

In 7 days compared to the control the increase of TNF-alpha in 17.88 times $(p<0.001)$ was observed, as well as the decrease of IL-1 beta by $45.81 \%(p<0.001)$, IL-2 - by $47.97 \%$ $(p<0.001)$, IL-4 - by $20.54 \%(p<0.001)$, and compared with the previous period of study, IL-1 beta was decreased by $55.57 \%(p<0.001)$, IL-10 - by $16.57 \%(p<0.001)$, IL-6 was increased by $70.81 \%(p<0.01)$, TNF-alpha - in 2.53 times $(p<0.001)$, IL-4 - by 31.69\% $(p<0.001)$.

In 14 days compared to the control the increase of TNF-alpha in 19.69 times $(p<0.001)$ was evidenced, as well as the decrease of IL-1 beta by $40.45 \%(p<0.001)$, IL-2 - by $37.84 \%(p<0.001), I L-4-$ by $21.08 \%(p<0.001)$, IL-10 - by $39.67 \%(p<0.002)$, and compared with the previous study period the decrease of IL-10 by $47.28 \%(p<0.001)$.
In 21 days compared with the control, the increase of TNF-alpha in 2.1 times $(p<0.001)$, IL- 6 - by $72.91 \%(p<0.001)$, the decrease of IL-4 by $28.06 \%(p<0.001), I L-2-$ by $22.30 \%(p<0.02)$, and compared with a previous period of study the decrease of TNF-alpha by $89.87 \%(p<0.001)$, increase of IL- 6 by $70.73 \%(p<0.001)$ and IL-10 by $78.85 \%(p<0.001)$ were present.

In 28 days the increase of TNF-alpha in 25.89 times $(p<0.001), I L-6-$ by $36.94 \%(p<0.02)$, the decrease of IL-1 beta by $45.38 \%(p<0.001)$, IL-2 by $35.13 \%(p<0.001)$, IL-4 - by $19.52 \%(p<0.001)$, and compared to the previous period of study, the increase in TNF-alpha in 11.87 times $(p<0.001)$, and the decrease of IL-1beta by $39.43 \%(p<0.05)$ were evidenced.

Injections of quercetin for 7 days caused a significant decrease of IL-2 by $62.84 \%(p<0.001)$, IL-4 - by $32.32 \%(p<0.001)$, IL-10 - by $51.92 \%$ $(p<0.001)$, and increase of IL- 6 in 2.7 times $(p<0.001)$.

In 7 days after the injury, quercetin correction proved increased level of IL-1 beta in 2.61 times $(p<0.001)$, IL- 4 - by $35 \%(p<0.001)$, IL-6 - in 2.27 times $(p<0.001)$, and decrease of TNF-alpha in 32.99 times $(p<0.001)$. In this period, IL-2, IL-4, IL-10 levels did not significantly differ from the control ones, and IL-1 beta was increased by $41.6 \%(p<0.001)$, IL-2 - by $29.73 \%$ $(p<0.001)$, IL-6 - in 2.54 times $(p<0.001)$. IL-1 beta level was also higher by $60 \%(p<0.01)$, TNFalpha - in 9.26 times $(p<0.001)$, IL-4 - by $58.5 \%$ $(p<0.002)$, IL-10 - in 2.69 times $(p<0.001)$ compared to the quercetin level.

In 14 days after the injury, the quercetin correction proved higher level of TNF-alpha by $55.14 \%(p<0.01)$ and IL-10 by $84.76 \%(p<0.001)$. In this period, only IL-10 level did not significantly differ from the control ones, IL- 6 was increased by $49.59 \%(p<0.05)$, TNF-alpha - in 32.1 times $(p<0.001)$, IL-1 beta was decreased by $28.5 \%$ $(p<0.01), I L-2-$ by $28.38 \%(p<0.001), I L-4-$ by $23.7 \%(p<0.001)$, and compared to a previous period of study IL-1 beta was decreased by 49.5\% ( $p<0.001)$, IL- 6 - by $40.97 \%(p<0.002)$, and IL-4 - by $28.87 \%(p<0.05)$, TNF-alpha was increased in 2.68 times $(p<0.001)$. IL-2 was also higher in 1.93 times $(p<0.001)$, TNF-alpha - in 24.8 times $(p<0.001)$, IL-10 - in 2.32 times $(p<0.001)$ and IL- 6 was lower by $44.7 \%(p<0.01)$ compared to the quercetin level.

In 21 days after the injury, the quercetin correction proved higher level of $\mathrm{H}-6$ by $51.42 \%$ $(p<0.002)$, TNF-alpha in 9.59 times $(p<0.001)$, lower level of $\mathrm{H}-2$ by $50.43 \%(\mathrm{p}<0.001)$. In this period, only IL-1 beta level did not significantly differ from the control, $\mathrm{H}-6$ was higher in 2.62 times $(p<0.001)$, TNF-alpha - in 20.1 times $(p<0.001)$, IL-10 - by $20.07 \%(p<0.001)$, IL- 2 was 


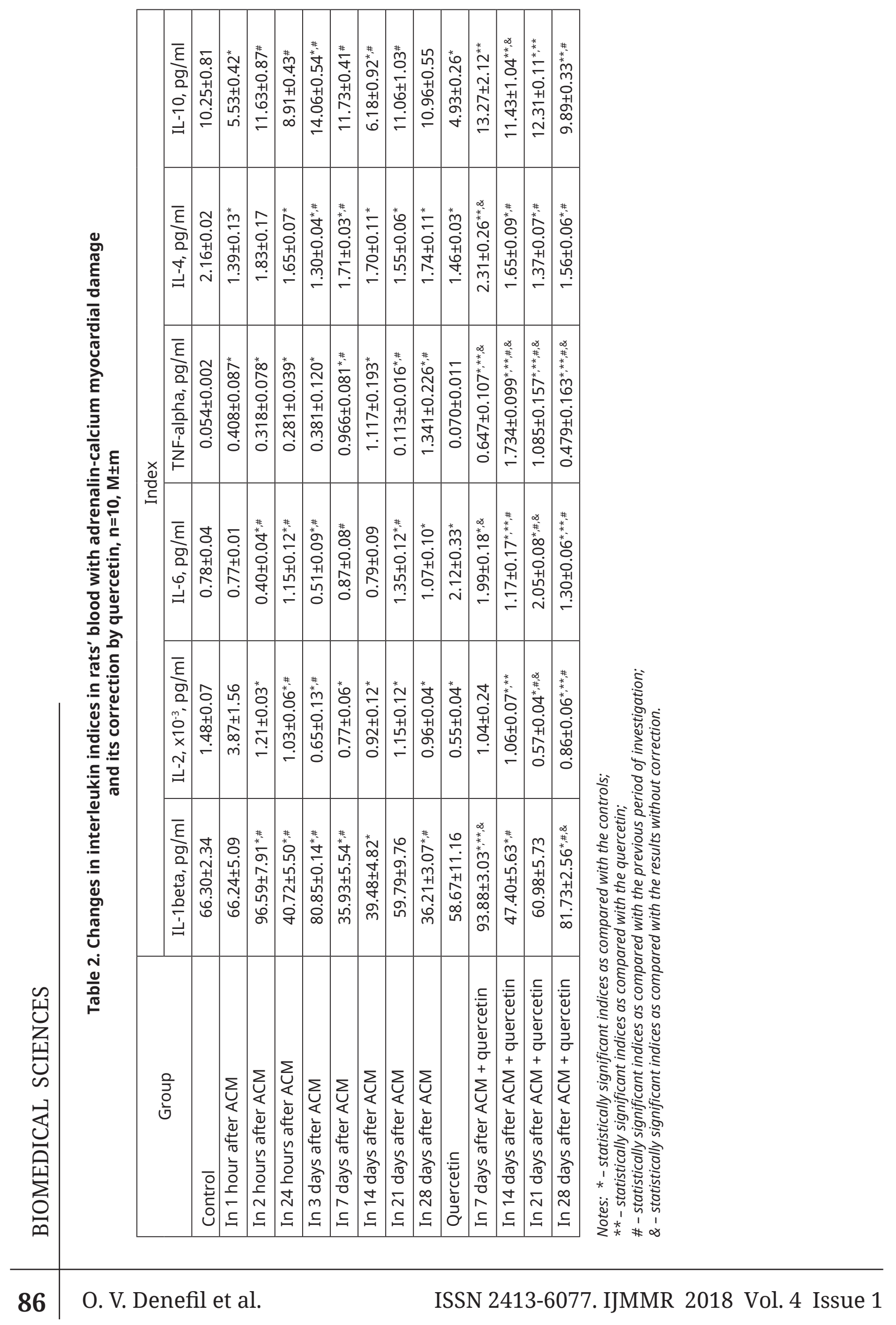


lower by $61.49 \%(p<0.001)$, IL-4 - by $36.5 \%$ $(p<0.001)$, and compared with a previous period of study the decrease of IL-2 by $46.23 \%(p<0.001)$, TNF-alpha - by $37.4 \%$ ( $p<0.001)$, IL-4 - by $16.77 \%$ $(p<0.05)$, the increase of IL- 6 by $74.91 \%(p<0.002)$ were present. TNF-alpha was also higher in 15.53 times $(p<0.001)$ and IL-10 - in 2.5 times $(p<0.001)$ compared to the quercetin level.

In 28 days after the injury, the quercetin correction proved higher level of IL-1 beta in 2.26 times $(p<0.001)$, lower level of TNF-alpha by $64.38 \%(p<0.01)$. In this period, only IL-10 did not significantly differ from the control level, IL-1 beta was higher by $23.28 \%(p<0.001)$, IL- 6 by $65.62 \%(p<0.001)$, TNF-alpha - in 8.87 times $(p<0.01), I L-2$ was lower by $41.89 \%(p<0.001)$, IL-4 - by $27.48 \%(p<0.001)$, and compared with a previous period of study the decrease of IL- 6 by $36.74 \%(p<0.002)$, TNF-alpha by $55.88 \%$ $(p<0.001)$, IL-10 by $19.68 \%(p<0.001)$, the increase of IL-1 beta by $34.04 \%(p<0.001)$, IL-2 by $50.88 \%(p<0.001)$, IL-4 by $14.19 \%(p<0.05)$ were present. IL-2 level was also higher by $56.36 \%(p<0.001)$, TNF-alpha - in 6.85 times $(p<0.05)$ IL-10 - in 2 times $(p<0.001)$, and IL-6 was lower by $38.82 \%(p<0.05)$ compared to the quercetin level.

\section{Discussion}

In first hour a direct damage of heart muscle by adrenaline was present, since the proinflammatory cytokine TNF-alpha was a mediator of cardiac pathology. TNF-alpha was synthesized by activated macrophages, and also stimulated them, promoted cytotoxic, immunomodulating, anti-inflammatory action. Decreases in IL-10 and IL-4 may be associated with the early period of damaging effects of adrenaline and calcium when the increase of one anti-inflammatory cytokine was sufficient with protection.

In two hours a high TNF-alpha content still was present. It could cause damage to endothelial cells, increase of microvascular permeability, activate the hemostasis system with DIC syndrome development. Normalizing the concentration of IL-4 and IL-10 may evidence development of immune response with involvement of $\mathrm{T}$ - and B-lymphocytes. That was evidenced by the increase of IL-1beta. The decrease of IL-2 and IL-6 proved immunosuppressive effect.

In day 1 high values of TNF-alpha and IL-6, in the presence of decreased IL-4, may evidence the activation of coagulation hemostasis with the development of blood clots. The increase of IL- 6 also evidenced development of hypoxia, which may take place due to necrosis of cardiomyocytes.

The increase of IL-1beta and TNF-alpha in day 3 could be caused by more severe hypoxia and ischemia, products of fibrin degradation. The increase of IL-10 proved its protective influence. in day 7 , compared to the previous period, IL-6 normalization may evidence the worsening of hypoxia. TNF-alpha increase and decrease of $\mathrm{H}-10$ only confirmed this assertion. That was observed in 14 days also.

In 21 and 28 days the same changes as in a 24 hour period were present: high level of TNFalpha and IL- 6 in the presence of decreased IL-4. It may prove the secondary activation of coagulation hemostasis by means of alteration.

In the infarcted myocardium, necrotic cardiomyocytes release danger signals activating an intense inflammatory reaction that serves to clear the wound from dead cells and matrix debris, but may also extend injury. Dead cardiomyocytes release IL- $1 a$ that may function as a crucial alarm in triggering the post-infarction inflammatory reaction. IL-1 $\beta$ is markedly up-regulated in the infarcted myocardium; activation of inflammasome in both cardiomyocytes and interstitial cells results in release of bioactive IL-ip in the infarcted area. Binding of IL-1 to the type 1 receptor triggers an inflammatory cascade, inducing recruitment of proinflammatory leukocytes and stimulating a matrix-degrading program in fibroblasts, while delaying myofibroblast conversion. IL-1 mediates dilative remodeling following infarction and may influence on the pathogenesis of postinfarction heart failure [7].

Injection of quercetin in the experiments increased contents of IL- 6 , suppressing the formation of IL-2, IL-4 and IL-10. Adrenaline and calcium lesion of heart in which quercetin was used had a favorable course. Thus, in 7 days, the decreased activation of TNF-alpha was observed, and increased - of IL-4, IL-6, and IL-1 beta. In 14 days, the increased activation of TNFalpha, normalization of $\mathrm{H}-10$ to the control level was evidenced. The increased content of IL-6, decreased - of IL-1 beta, IL-2, IL-4 were present. In 21 days, the increased content of TNF-alpha, IL-6 was evidenced. IL-10 level did not differ from the control, IL-2 content was decreased. In 28 days, the increased activation of IL-1beta, decreased content of TNF-alpha was observed.

IL-10 improved myocardial function after acute global I/R and suppressed inflammation of STAT3 pathway [8]. Also the profibrotic effect of IL-10 autocrine loop promoted macrophages to secret osteopontin and TGFp. These mediators activated cardiac fibroblasts to produce collagen that caused cardiac fibrosis and increased cardiac stiffness [9]. Increased IL-6 content was associated with a cardiovascular disease and protected cells against apoptosis whilst being important for normal metabolism [10]. 
The obtained data has proved the inclusion of pro- and anti-inflammatory mechanisms of protection against damage, when used with the protective effect of quercetin. Quercetin in cases of more severe fibrosis with underlying injury of ACM of rats prevents cardiac necrosis.

\section{Conclusions}

The development of adrenaline-calcium heart damage is accompanied by bright cytokine wavelike reaction at different time points. In early time a direct damage of heart muscle by adrenaline and calcium is present. Then can be development of DIC syndrome, immune response, hypoxia, and ischemia. At day 3 increases the protective influence - anti-inflammatory interleukins level. Then evidence the worsening of hypoxia, secondary activation of coagulation hemostasis by means of alteration. Quercetin causes normalization of interleukins level.

\title{
ЗМІНИ ПРОЗАПАЛЬНИХ ТА ПРОТИЗАПАЛЬНИХ ЦИТОКИНІВ НА МОДЕЛІ АДРЕНАЛІНОВО-КАЛЬЦІЄВОГО УРАЖЕННЯ МІОКАРДА У ЩУРІВ ТА КОРЕКЦІЇ КВЕРЦЕТИНОМ
}

\author{
О. В. Денефіль, А. М. Мусієнко \\ ТЕРНОПІЛЬСЬКИЙ ДЕРЖАВНИЙ МЕДИЧНИЙ УНІВЕРСИТЕТ IМЕНІ І. Я. ГОРБАЧЕВСЬКОГО, ТЕРНОПІЛЬ, УКРАЇНА
}

\begin{abstract}
Вступ. Серцева недостатність є однією з основних причин захворюваності та смертності у світі.
Метою дослідження було визначення коливань інтерлейкінів на моделі адреналіново-кальцієвого ураження міокарда та його корекції кверцетином.

Методи. Досліди проведені на 143 щурах-самцях лінії Вістар віком 5-6 місяців. Було досліджено зміни вмісту інтерлейкінів IL-1 beta, IL-2, IL-4, IL-6, IL-10, TNF-альфа у сироватиі крові при розвитку ураження серия та застосування кверцетину. Дослідження проводили у 1-у, 2-у, 24-у години, на 3-ю, 7-у, 14-у, 21-у та 28-у доби.

Результати. Адреналіно-кальцієва модель ураження міокарда характеризувалася підвищенням рівня TNF-альфа; а вміст IL-2 ma IL-4 поступово достовірно знижувався. Рівень IL-1бета зростав на 2-у і 3-ю доби після формування ураження серцевого м'яза, у інших періодах часу досліджень (за винятком 1 години і 21-їдоби) ці показники знижувалися. Спостерігалися також хвилеподібні коливання вмісту IL-6 і IL-10.

Iн'єкції кверцетину протягом 7 днів зумовили достовірне зниження IL-2, IL-4, IL-10 та підвищення вмісту IL-6. Також спостерігалося зниження рівня TNF-альфа, та підвищення вмісту IL-4, IL-6 ma IL-1. Через 14 днів все ще спостерігалося підвищення рівня TNF-альфа та нормалізація показників IL-10. На 28-у добу зафіксовано підвищений вміст IL-1beta та зниження рівня TNF-альфа.

Висновки. Розвиток адреналіно-кальчієвого ураження серия супроводжується яскравою хвилеподібною реакцією читокінів у різні досліджувані проміжки часу час. Кверцетин викликає нормалізацію рівня інтерлейкінів.

КЛЮЧОВІ СЛОВА: адреналіново-кальцієва модель ураження міокарду; щури; кверцетин; інтерлейкіни.
\end{abstract}

\section{References}

1. Seg a AM, Frazier OH, Buja LM. Fibrosis and heart failure. Heart Fail Rev. 2014;19(2):173-85. doi: 10.1007/s10741-012-9365-4.

2. Frantz S, Hofmann U, Fraccarollo D, Schäfer A, Kranepuhl S, Hagedorn I, Nieswandt B, Nahrendorf M, Wagner H, Bayer B, Pachel C, Schön MP, Kneitz S, Bobinger T, Weidemann F, Ertl G, Bauersachs J. Monocytes/macrophages prevent healing defects and left ventricular thrombus formation after myocardial infarction. FASEB J. 2013;27(3):871-81. doi: 10.1096/fj.12-214049.

3. ashmi S, Al-Salam S. Acute myocardial infarction and myocardial ischemia-reperfusion injury: a comparison. Int J Clin Exp Pathol. 2015;8(8): 8786-96.

4. Weber KT, Sun Y, Bhattacharya SK, Ahokas RA, Gerling IC. Myofibroblast-mediated mechanisms of pathological remodelling of the heart. Nat Rev Cardiol. 2013;10(1):15-26. doi: 10.1038/nrcardio. 2012.158

5. Frangogiannis NG. Inflammation in cardiac injury, repair and regeneration. Curr Opin Cardiol. 2015;30(3):240-5. doi:0.1097/HCO.0000000000000158.
6. Sheremeta L. Antiulcerous activity of liposomal quercetin at experimental subacute gastric ulcer. Herald SSU. The series 'Medicine'. 2008;1:43-7. [In Ukrainian].

7. angogiannis NG. Interleukin-1 in cardiac injury, repair, and remodeling: pathophysiologic and translational concepts. Discoveries (Craiova). 2015; 3(1): e41. doi: 10.15190/d.2015.33

8. Manukyan MC, Alvernaz CH, Poynter JA, Wang Y, Brewster BD, Weil BR, Abarbanell AM, Herrmann JL, Crowe BJ, Keck AC, Meldrum DR. Interleukin-10 protects the ischemic heart from reperfusion injury via the STAT3 pathway. Surgery. 2011;150(2):231-9. doi.org/10.1016/j.surg.2011.05.017

9. Cih ova D. Interleukin-10 stiffens the heart. Journal of Experimental Medicine. 2018;215(5): DOI: $10.1084 /$ jem.20180049

10. ywardena MY, Leifert WR, Warnes KE, Varghese JN, Head RJ. Cardiovascular biology of interleukin-6. Current Pharmaceutical Design. 2009; 15:1809-21.

Received: 2018-05-03 